\title{
Review of Grid Codes: Ranges of Frequency Variation
}

\author{
Nikolay Ruban ${ }^{1, \text { a) }}$, Aleksey Kinshin ${ }^{1, b)}$ and Aleksandr Gusev ${ }^{1, c)}$ \\ ${ }^{1}$ National Research Tomsk Polytechnic University, 634050 Tomsk, Russia. \\ a) Corresponding author: rubanny@tpu.ru \\ b)aik36@tpu.ru \\ c)gusev_as@tpu.ru
}

\begin{abstract}
This article contains a review of grid codes throughout the world. Although grid codes addresses many issues, only four aspects related to generator-grid interaction are the most important: ranges of frequency variation, ranges of voltage variation, fault ride through capability, reactive power capability.
\end{abstract}

\section{INTRODUCTION}

This article contains a review of grid codes throughout the world. Although grid codes addresses many issues, only four aspects related to generator-grid interaction are the most important: ranges of frequency variation, ranges of voltage variation, fault ride through capability, reactive power capability. Table 1 details the reviewed European grid codes [1-5]. It must be noted the harmonizing efforts carried out in Europe by ENTSO-E (European Network of Transmission System Operators for Electricity).

TABLE 1. Reviewed European Grid Codes

\begin{tabular}{ccc}
\hline Country or Region & Regulator / Grid Code Author & Language \\
\hline Austria & Energie-Control Kommission & German \\
Belgium & Belgian Ministry of Economy & French / Flemish \\
Bulgaria & State Energy Regulatory Commission & Eng. \\
Czech Republic & Energy Regulation Office, CEPS & Czech / Eng. \\
Europe & ENTSO-E & Eng. \\
France & RTE & French \\
Great Britain & National Grid Electricity Transmission plc & Eng. \\
Germany & VDN & German / Eng. \\
Greece & ITSO & Greek / Eng. \\
Italy & TERNA S.p.A. & Italian \\
Lithuania & Lietuvos Energija & Eng. \\
Netherlands & Putoriteit, Consument \& Markt & Dutch/Eng. \\
Poland & PSE & Polish / Eng. \\
Romania & ANRE & Romanian / Eng. \\
Scandinavia & Nordel & Eng. \\
Spain & SwissGrid & Spanish \\
Switzerland & & French / German / Italian / Eng. \\
\hline
\end{tabular}

\section{RANGES OF FREQUENCY VARIATION}

Ranges of frequency variation requirement can be formulated in terms of variations in steady state (SS) and transient, interactions between frequency $(\mathrm{F})$, voltage $(\mathrm{V})$ and active power $(\mathrm{P})$ what is shown in the table 2 as F-V, F-P 
or F-V-P. In addition to the range of frequency variation, some grid codes impose a requirement on the rate-of- change of frequency (ROCOF) withstand capability. Table 2 details the ranges of frequency variation required by European grid codes [1-5].

TABLE 2. European grid codes: frequency variation

\begin{tabular}{cccc}
\hline Country or Region & $\begin{array}{c}\text { Steady state } \\
\text { Range, Hz }\end{array}$ & Transient Range, Hz & $\begin{array}{c}\text { Interactions between frequency, } \\
\text { voltage and active power }\end{array}$ \\
\hline Austria & $49-50.5$ & $47.5-51.5$ & F-V-P \\
Belgium & $48.5-51$ & $47.5-52.5$ & F-V-P \\
Bulgaria & $48.75-51.25$ & Fo & $\begin{array}{c}\text { F-P } \\
\text { Czech Republic }\end{array}$ \\
France & $48.5-50.5$ & $47.5-51.5$ & or V in transient \\
GB & $49.5-50.5$ & $47-55$ & No \\
Germany & $49-51$ & $47.5-51.5$ & Rated P for SS F ranges; P reduc- \\
Greece & $49-50.5$ & $47.5-51$ & tion with F reduction allowed \\
Italy & $49.5-50.5$ & $47-53$ & Rated P at SS V ranges \\
Lithuania & No & $47.5-52$ & No \\
Netherlands & $49.85-50.15$ & No & No \\
Poland & $49-51$ & $48-51$ & F-V-P \\
Romania & $49.5-50.5$ & $47.5-52.5$ & Rated P for SS F ranges \\
Scandinavia & $49-50.3$ & $49-52$ & F-V-P \\
Spain & $48-51.5$ & $47.5-52$ & F-V-P \\
Austria & $49-50.5$ & $47-51.5$ & No \\
& & $47.5-51.5$ & F-V-P \\
\hline
\end{tabular}

Table 3 European grid codes: ROCOF details the ROCOF required by European grid codes in term of the ROCOF itself and its duration.

TABLE 3. Reviewed European Grid Codes

\begin{tabular}{|c|c|c|}
\hline Country or region & ROCOF (Hz/s) & Duration (seconds) \\
\hline Austria & $0.2 \mathrm{~Hz} / \mathrm{s}$ & $10 \mathrm{~s}$ \\
\hline Germany & $0.09 \mathrm{~Hz} / \mathrm{s}$ & 10 \\
\hline Greece & $0.5 \mathrm{~Hz} / \mathrm{s}$ & - \\
\hline Ireland & $1 \mathrm{~Hz} / \mathrm{s}$ & - \\
\hline Switzerland & $0.09 \mathrm{~Hz} / \mathrm{s}$ & 10 \\
\hline Austria & $0.2 \mathrm{~Hz} / \mathrm{s}$ & $10 \mathrm{~s}$ \\
\hline GB & \multicolumn{2}{|c|}{$\begin{array}{l}\text { The System Frequency could rise to } 52 \mathrm{~Hz} \text { or fall to } 47 \mathrm{~Hz} \text {. Electrical } \\
\text { equipment must continue to operate within this Frequency range for at } \\
\text { least the periods of time given in CC.6.1.3 of British grid code }\end{array}$} \\
\hline
\end{tabular}

ENTSO-E has established the ranges of frequency variation requirements for 5 European regions (Baltic, Continental, Great Britain, Ireland and Nordic). Table 4 details the ranges of frequency variation required by ENTSO-E grid code in term of several features (steady-state variations, transient variation and F-V, F-P and F-V-P couplings). Figure 4 compares the ranges of frequency variation requirements of the five European frequency zones.

TABLE 4. ENTSO-E grid code: ranges of frequency variation

\begin{tabular}{cccl}
\hline Country or Region & Steady state Range, Hz & Transient & \multicolumn{1}{c}{ Country or Region } \\
\hline European & $49-51$ & $47.5-51.5$ & $\begin{array}{l}\text { The time limitation for the fre- } \\
\text { quency decreasing applies. }\end{array}$ \\
Union (EU)- & $49-51$ & $47.5-51.5$ & $\begin{array}{l}\text { P reductions during operation at } \\
\text { low frequencies broadly de- } \\
\text { Continental }\end{array}$ \\
EU-Nordic & $49-51$ & $47-52$ & fined \\
EU-Great & $49-51$ & $47.5-51.5$ & \\
Britain & & \\
EU-Ireland & &
\end{tabular}


ENTSO-E grid code states with regard to ROCOF "Generators must withstand a rate of change of frequency specified by the TSO during a certain time without disconnection". The ENTSO-E code on requirements for grid connection of high voltage direct current systems and direct current-connected power park modules states that "An HVDC system shall be capable of staying connected to the network and operable if the network frequency changes at a rate $2-2,5 \mathrm{~Hz} / \mathrm{s}$ (measured at any point in time as an average of the rate of change of frequency for the previous $1 \mathrm{~s}$ )".

\section{CONCLUSION}

Frequency variations occur in power systems due to active power generation and demand unbalances. The magnitude of the frequency variation depends on the magnitude of the generation-demand unbalance compared to the size of the system assuming that:

- $\quad$ primary frequency regulation reserves are greater than the generation-demand unbalance,

- frequency load shedding schemes are not activated, and

- $\quad$ primary frequency regulation system performs ideally (it is provided by all generators)

Duration of frequency excursions depend on the performance of primary, secondary and tertiary frequency regulation systems. Not only the dynamic performance of the components of the frequency regulation system is relevant but the magnitude of the reserves affects as well.

The initial rate-of-change of frequency in case of depends on the size of the generation-demand imbalance compared to the rating of the on-line synchronous generators. Frequency variation requirements imposed by grid codes are not uniform at all. Wider and longer frequency excursions are usually required in smaller systems with less performing frequency regulation systems. Rate-of-change of frequency withstand capability is also usually required in smaller (isolated) systems. It is worth to note that large rate-of-change-of-frequency occurs only in large interconnected systems in case of disturbances much more severe than the design disturbance of the system. Developments towards operation sometimes dominated by Power Electronic Power Sources (PEIPS), widely results in reducing system inertia. Analyses by ENTSO-E shows up to 10 fold reduction in p.u. for the system inertia. Therefore, codes are increasingly considering introducing requirements for PEIPS to contribute inertial systems.

\section{ACKNOWLEDGMENTS}

The reported study was funded by RFBR according to the research project No 18-38-00821.

\section{REFERENCES}

1. E.ON Netz GmbH, Grid Connection Regulations for High and Extra High Voltage, 2006 see https:// www.nerc.com/docs/pc/ivgtf/German_EON_Grid_Code.pdf.

2. The Grid Code Issue 5 Revision 33, 2006 available at https://www.nationalgrideso.com/document/33821/download.

3. Grid Code Specifications for Power Generating Facilities VJV 2018, available at https://www.fingrid.fi/en/services/power-transmission/grid-connection-agreement-phases/specifications-for-the-operational-performance-ofpower-generating-facilities/.

4. Transmission Code 2008 TC 2008, available at https://www.nerc.com/docs/pc/ivgtf/German_EON_Grid_Code.pdf.

5. Instruction of transmission system operation and maintenance, Version 1.2 Effective date: 1st of June 2006, available at https://www.pse.pl/documents/31287/fd6e904e-90de-4dda-aad5d8486a885eec? safeargs $=646 \mathrm{f} 776 \mathrm{e} 6 \mathrm{c} 6 \mathrm{f} 61643 \mathrm{~d} 74727565 /$. 